\title{
NEW JERSEY \\ DEFIES THE CONFEDERATION: \\ AN ABRAHAM CLARK LETTER
}

\author{
BY RICHARD P. McCORMICK
}

\begin{abstract}
Dr. MCCoRMICK is an Assistant Professor of History in the Department of History and Political Science and University Historian. A specialist in the field of New Jersey History, his Experiment in Independence: New. Jersey in the Critical Period, I781-I789, was published by the Rutgers University Press in April.
\end{abstract}

THROUGH the generosity of the Friends of the Library, Rutgers recently acquired an unusually fine and significant letter written by Abraham Clark. This document, of four closely written pages, recites in detail the basis of New Jersey's opposition to the financial practices of the Continental Congress and provides the background for one of the actions that was to contribute to the downfall of the Confederation, that is, New Jersey's refusal to honor a requisition from the Congress.

The author of the letter was born in Elizabeth in I 726, followed the trades of surveyor and farmer, and devoted his talents to becoming one of the state's outstanding political figures. A signer of the Declaration of Independence, member of the Continental Congress, and state assemblyman, Clark was later to attend the Annapolis Convention and sit in the Federal Congress from I79r until his death in I794. As a champion of paper money and other popular causes, he was regarded by his opponents as a crafty, eccentric demagogue. Actually he was a professional politician with democratic tendencies who shrewdly acted on his judgment of the popular temper. ${ }^{1}$

As a member of the Assembly from Essex County in I785, Clark was the acknowledged leader of the majority party. One of the major problems that confronted this session was what action to take on a requisition from the Continental Congress. The issues involved were large, for the Confederation was rapidly approaching financial collapse and, unable to meet its foreign and domestic obligations,

\footnotetext{
1 There is no adequate biography of Clark and few of his letters have been preserved.
} The most satisfactory brief sketch is in the Dictionary of American Biography, IV, I I8-I 9. 
was disintegrating. On the other hand, New Jersey had very serious grievances against the requisition system of finance. Because it had neither vacant public lands to sell nor foreign imports to tax, it could - unlike most states-secure money to meet requisitions only by levying direct taxes on its citizens.

Ever since I 778 New Jersey had insisted that the Confederation should be empowered to levy a modest impost or tariff, but efforts to grant the central government such powers in 1780 and again in I 783 had come to naught. Consequently, the state had in 1783 declared its financial independence of the Confederation and formally announced that it would honor no future requisitions until the impost had been adopted. Moreover, it took upon itself the responsibility for paying the interest on Confederation securities held by its own citizens. ${ }^{2}$

After I 782, the Continental Congress levied no requisitions until September, I 785. Then it called for three million dollars, one third of which was payable in specie and the remainder in indents, i.e., certificates given in place of cash for interest due on Confederation securities. The interest certificates were not to be issued unless a state complied fully with the requisition. Furthermore, if any state continued making its own interest payments - as New Jersey was doing-to its own citizens, such payments were not after January I, I 786 , to be credited as a future charge against the United States. New Jersey's quota of the requisition was $\$ 166,716$. $^{3}$

The legislature was faced with a dilemma. If it refused to honor the requisition, those of its citizens who held securities would not receive indents and the heavy expenditures the state was making to pay interest on the debt would not be recognized. If, however, the requisition was to be met, the state would have to tax itself heavily and retreat from a position it had taken in 1783 .

This was the situation, then, which confronted Clark and his colleagues when the legislature met in November, I 785. On Clark's motion, consideration of the problem was postponed to the next sitting, which was to be held in February, 1786 . In the meantime, Clark set forth his objections to the requisition in his letter to two of New

2 Acts of the Council and General Assembly of the State of New Jersey. . ., compiled by Peter Wilson (Trenton, 1784), pp. 363-77.

3 Journals of the Continental Congress, XXIX, pp. 765-7I. 
Jersey's delegates in Congress and aired his views in the press as well. ${ }^{4}$

Following the leadership of Clark, the Assembly resolved on February 20 by a vote of thirty-two to three not to comply with the requisition, at the same time repeating its familiar plea for an impost. This defiant action shocked the Congress, and a three-man committee was at once appointed to go to Trenton to remonstrate with the legislature. The Continental emissaries were permitted to present their case on March I3, and although they did succeed in securing the repeal of the resolution of February 20 , they were unable to induce the legislators to vote any funds for the requisition.

Coming at the time that it did, this action by New Jersey was a major blow to the Confederation. "Is it possible," James Madison wrote to his good friend James Monroe, "with such an example before our eyes of impotency in the federal system to remain skeptical with regard to the necessity of infusing more energy into it?" Soon, he maintained, it must be decided whether the union was worth preserving. ${ }^{5}$ One of the members of the committee of Congress, after he had returned from Trenton, noticed that there were "serious thoughts in the minds of some of the Members of Congress to recommend to the States the meeting of a general Convention to consider an alteration of the Confederation. . "" Possibly his recent experience in New Jersey was in the mind of another member of the committee, Charles Pinckney, when in May he proposed that Congress should go into the committee of the whole on the state of the nation, a proposal which was to result two months later in the appointment of a grand committee to report such amendments to the Articles of Confederation as would "render the federal government adequate to the ends for which it was instituted." Certainly New Jersey's action must be regarded as a major incident in the train of events that led up to the calling of the Constitutional Convention and the formation of the Federal Union.

Clark's letter to John Cleves Symmes and Josiah Hornblower,

4 "A Fellow Citizen" [Abraham Clark], (Elizabeth Town) Political Intelligencer, Jan. II, Feb. 8, 1786 .

5 The Writings of James Madison. . . , ed. by Gaillard Hunt (9 vols., New York, 1902), II, p. 235 .

${ }^{6}$ Edmund C. Burnett, ed., Letters of Members of the Continental Congress (8 vols., Washington, I921-1936), VIII, p. 333.

${ }^{7}$ Edmund C. Burnett, The Continental Congress (New York, r941), pp. 647, 663; Journals of the Continental Congress, XXX, p. $3^{87}$ n; ibid., XXXI, pp. 494-98. 
two of the state's three delegates in the Continental Congress, is printed below in full.

Gentlemen,

\author{
Eliza[beth] Town Decem[be]r 9th 1785
}

The Resolution of Congress of the $27^{\text {th }}$ of Septem ${ }^{\mathbf{r}}$ last for raising three Million of dollars, was before the House of Assembly Last Sitting, but as the effects of it might not at first View be fully comprehended, and not chusing to Act with an implicit faith in the Wisdom of Congress, we wished to give it due Consideration, and thereupon referred it to next sitting which will be the middle of February: What the issue of it will then be, I need not attempt to predict. My present sentiments, notwithstanding the fine name of Facilities given to it by the Treasury board, are not much in its favor. It may be a Wise measure, but if so, its Wisdom is buried too deep for my penetration. Several weighty objections appear in my mind both against the policy and justice of the Resolution, some of which will Necessarily Operate against its adoption in this State; Others will only apply to it in Case of its Rejection.

First, It is either a designed Scheme to Supercede the Necessity of a general Impost; or if not designed, will Assuredly have that effect: nothing to the Contrary is held out in it; No intimation is given that it is designed as a temporary expedient untill an impost can take effect: And notwithstanding that Charity which hopeth and believeth all things, I am fully persuaded this Scheme is by some intended to give a final Stab to the impost, tho' not long since it was the General opinion, not only of Congress, but all cool and considerate Men, that an impost was the only practicable means of procuring money to pay the Interest of our foreign Debt, and that it is the most easy and equitable mode of raising a revenue; but now, contrary to the experience of all Nations, we are to Obtain the Necessary supplies only by Taxation. It is confessed by all that we ought to pay the Interest of our Debt both foreign and Domestick, but neither the Justice or Magnanimity of some of the States will suffer it to be done in the way, and the only way in which it can be done. To Attempt to raise by Taxation the Sum required in Specie will be vain and fruitless; in this State it cannot be done. The measure proposed will no doubt meet with the Approbation of some of the trading States. New York and Pennsylvania can raise their Quota of Specie by State imposts, to which our Citizens by trading with them will contribute as much as theirs in proportion to their Numbers, and after all will have the full Quota of this State to pay besides: This is a burden too unequal and grievous for this State to Submit to. We are ready to bear our part in the defence, and also of the expence necessary in Support of the Union, provided the same can be done in a just equal and practicable way, but Oppression will make even a Wiseman mad.

Secondly, the Quota Assigned us is far beyond our proportion: ${ }^{8}$ This is not

${ }^{8}$ Clark wrote in the margin of his letter: "Note this part was Stated upon a Mistake \& misinformation which I soon after discovered \& publickly Acknowledged." See (Elizabeth Town) Political Intelligencer, Feb. 8, 1786. Actually, New Jersey's quota was 
a random conjecture, but founded on facts; for I find the present Quota is taken from that of the 18 th of April 1783 , in the Settlement of which recourse was had to the Number of Inhabitants in each State as given in by mere supposition the beginning of the War, when each State endeavoured to appear as formidable and important as possible without considering after Consequences; this was to govern where no clearer accounts could be had: In this Estimate New Jersey stood at 200,000: At this Settlement of Quotas most of the States produced Accounts Actually taken of their Numbers, which if I rightly remember in all cases fell greatly short of the Numbers they had before been Estimated at: New Jersey then had not taken an Account of theirs, or could any documents be produced to prove the former Estimate eronious, as was done by some States where their Numbers were not exactly known; the Consequence was, we was rated at the 200,000. Our Number hath since been taken with Exactness, and by the return forwarded to Congress near a year ago, their Numbers reckoning three fifths of the blacks Amounts only to I45,234, which would reduce our present Quota about 43,750 dollars less than assigned us. This is upon a supposition the other States are not rated too high, which is not probable, as their Numbers since 1783 hath encreased by the return of their Citizens and disbandment of the Army. Why, at the last settlement, no attention was paid to our Quota, when the means for rectifying the former error was in the power of Congress, and the error so notorious, is not in my power to Comprehend. Did Congress think the sum of 43,750 dollars a sum so trifling, and with respect to New Jersey, of so little Consequence as not to be worth troubling themselves about a Calculation? Or did they suppose we should be made perfectly easy by the fine dozing frill usually given upon all such Occasions, that we are to be Creditted and Righted at some future adjustment? Which I understand to be at the day of Judgment: a kind of trust we can by no means give.

Thirdly, The plan if carried into effect reduces all Notes given for Interest into one common Mass, whereby those given on Commutation Notes will not be distinguishable from others: On which Subject the Sentiments of our Legislature have been so often expressed, that a repetition is unnecessary. ${ }^{2}$ They have no Objection to Congress paying the Officers their Commutation with the back lands, and this I have always understood would be Sattisfactory to the Officers of this State; But to raise money by Taxes for this purpose cannot in my opinion be done here even if the Legislature should attempt it, such a Law would be almost Universally Opposed, and for that reason could not be executed.

computed on the basis of a population of I 30 , ooo. "Federal," (Elizabeth Town) Political Intelligencer, Feb. I, I 786 .

${ }^{9}$ Commutation notes were granted to Revolutionary officers in March, ${ }_{17} 8_{3}$, in amounts equal to their pay for five years. New Jersey had opposed this grant and did not wish to be taxed to pay off the notes. Burnett, Continental Congress, p. 568 . 
Fourthly, The Commissioner of the Loan office in each State ${ }^{10}$ is forbid to issue any Notes for Interest untill the Legislature of the State shall pass a Law for carrying the Resolution into effect: What is this for? Notes indeed might be of no great consequence, but what then if they chose them? why this discrimination of Credittors? They Loaned their money in their private Capacity to Congress, it was then of no Consequence where they resided; in that Transaction they had no connection with one State more than another; they did not trust a State, but the United States; As their Creditors they are entitled to equal Advantages from Congress, live where they will: It was no stipulation in the Contract that they were to be paid only in Case the Legislature of the State where they resided should in all Cases follow the dictates of Congress; And yet this is now the term fixed by Congress on which, giving only An Acknowledgment of the Interest due, is Suspended.

These last remarks have nothing to do with the main Question, whether we will adopt the plan or not, otherwise than as it refers to the general Spirit of the System, which Appears liable to exceptions in almost every part, in which view I likewise consider what follows.

Fifthly, That no State is to be Creditted after the first of January next for Interest they may pay contrary to the true intent of the requisition. That we are daily paying Interest upon Continental Certificates, while the Creditors of this State go unpaid, is a truth well known. ${ }^{11}$ For this Voluntary Act to support the Credit of the United States, and give relief to their Suffering Creditors in preference to our own, what do we get? - the thanks of Congress? No,- - but their severe threats in case we do the like in future. In what does our crime of liberality consist? We raise more than our Quota of Interest on the Domestick Debt, and we pay it punctually to our Citizens who are Creditors to the United States, and have trusted the Continent more than the Citizens of any other State have done, on which Account they are at least as meritorious as any of the publick Creditors, and from the ravages of War in almost every part of the State are in as much or greater need of their Interest: In doing this we do Acts of Mercy and Justice, by relieving those in distress, and making the burden fall as equally as possible on all, and in effect do all that is now required of us respecting the Domestick Debt, tho' not precisely in the way demanded, for we pay out our Quota in Bills which answers in lieu of Cash in trade, as their credit is Supported by being all Called in again by Taxes in the course of the year: $:^{12}$ Whereas by the Scheme proposed, Notes

${ }^{10}$ The Commissioners were responsible for selling loan-office certificates, which were interest-bearing notes issued on the faith and credit of the Confederation, and for making interest payments on the certificates when funds were available. By the terms of the requisition of 1785 , they were to pay out indents in place of specie for interest.

${ }^{11}$ Although the state had assumed the obligation of making interest payments on Confederation securities in 1783 , it made no adequate provision for interest payments on the state debt until 1787. Acts of the. . . General Assembly of the State of New Jersey, Eleventh Session, Second Sitting, Act of June 7,1787 .

${ }^{12}$ To pay the interest on Confederation securities, the state issued $\$ 83,358$ in "revenue money." This was called in by taxes each year and then was used again for interest payments. Wilson, Acts, pp. 363-77. 
are to be issued for all the Interest in Arrear[s], which I suppose will be about five years, of which the Tax to be levied will take in only the one fifth part; and before another years tax becomes payable, if the requisition should be renewed, another Years Interest equal thereto will be issued, by which means four fifths of the Notes must remain useless to the holders, as they can be passed for no other purpose than that of paying those particular taxes for which while new ones are issued they cannot be wanted, and can never Answer the good purposes produced by our mode of payment; Notwithstanding this, if we continue those payments, we are not, say Congress, to be Creditted for the same. What then must be done, may we not in such a case Credit our selves with the United States? Undoubtedly, in the Opinion of all the world we may, and Congress cannot Object to it.

Please to excuse the length of this Letter, and believe me to be,

With sincere regard,

Gentlemen,

Your Obed! Hum. Serv ${ }^{\mathrm{t}}$

Hon $^{\text {ble }}$ John C. Symm [e]s

[signed] Abra: Clark

\& Josiah Hornblower Esquires

P.S. You are to make what use you think proper with this Letter. I should have also Addressed it to Mr. Cadwallader, ${ }^{13}$ but have not an Acquaintance with him to justifie such a freedom.

${ }^{13}$ Lambert Cadwallader, the third member of the New Jersey delegation in the Continental Congress. Adequate sketches of Symmes, Hornblower, and Cadwallader may be found in the Dictionary of American Biography. 